Article

\title{
Valorization of Cotton Gin Trash through Thermal and Biological Conversion for Soil Application
}

\author{
Qurat-ul-Ain $^{1}$, Aisha Nazir ${ }^{1, * \mathbb{D}}$, Sergio C. Capareda ${ }^{2} \mathbb{D}$, Muhammad Shafiq $^{1}$ and Firdaus-e-Bareen ${ }^{1}$ \\ 1 Environmental Biotechnology Laboratory (F4), Institute of Botany, University of the Punjab, \\ Lahore 54590, Pakistan; quratulain_486@yahoo.com (Q.-u.-A.); mshafiq.botany@pu.edu.pk (M.S.); \\ firdaus.botany@pu.edu.pk (F.-e.-B.) \\ 2 Biological and Agricultural Engineering Department, Texas A\&M University, College Station, TX 77843, USA \\ scapareda@tamu.edu \\ * Correspondence: aisha.botany@pu.edu.pk
}

check for

updates

Citation: Qurat-ul-Ain; Nazir, A.; Capareda, S.C.; Shafiq, M.; Firdaus-e-Bareen Valorization of Cotton Gin Trash through Thermal and Biological Conversion for Soil Application. Sustainability 2021, 13, 13842. https://doi.org/10.3390/ su132413842

Academic Editors: Balal Yousaf and Guijian Liu

Received: 1 November 2021 Accepted: 10 December 2021 Published: 15 December 2021

Publisher's Note: MDPI stays neutral with regard to jurisdictional claims in published maps and institutional affiliations.

Copyright: (c) 2021 by the authors. Licensee MDPI, Basel, Switzerland. This article is an open access article distributed under the terms and conditions of the Creative Commons Attribution (CC BY) license (https:/ / creativecommons.org/licenses/by/ $4.0 /)$.

\begin{abstract}
Cotton gin trash, the by-product of the cotton ginning industry which is produced in large quantities every year, can be utilized as feedstock for deriving high quality organic materials such as biochar, compost and co-composted derivates for improvement of soils' key physical, chemical and biological properties. This is the first report in which cotton gin trash was both thermally and biologically converted at the same time into biochar (BC), compost (C) and co-compost (Coc), and their effects on soil properties and on plant performance were examined. In order to find the optimum rate, the products were used as soil amendments in a greenhouse experiment at $2.5 \mathrm{tha}^{-1}, 5 \mathrm{t} \mathrm{ha}^{-1}$ and $10 \mathrm{t} \mathrm{ha}^{-1}$ rates. All of the amendments contributed in improving the soil properties and provided agronomic benefits to plants, however plants (radish var. Cherry belle) showed significantly $(p<0.05)$ better growth attributes and almost a 315\% increase in biomass yield observed when co-composted biochar $\left(10 \mathrm{t} \mathrm{ha}^{-1}\right)$ was applied to the soil, thus suggesting its role in compensating fertilizer application. Amendments ( 2.5 and $5.0 \mathrm{t} \mathrm{ha}^{-1}$ ) considerably increased plant growth parameters; however, differences between 5 and $10 \mathrm{t} \mathrm{ha}^{-1}$ amendments were not so significant. As a result, replenishing soil with $\operatorname{Coc}\left(5 \mathrm{t} \mathrm{ha}^{-1}\right)$ on a regular basis can promote plant growth and improve soil qualities over time.
\end{abstract}

Keywords: cotton gin trash; biochar; gasification; co-compost; compost; soil management; plant growth

\section{Introduction}

Cotton is the principal source of natural fibers for textile industries, and global cotton consumption was estimated to be around 26 million tons in 2016-2018 [1]. The cotton industry generates approximately 50 million tons of waste biomass each year [2]. Cotton gin trash, a byproduct of the ginning industry, consists of small sticks, leaves, cottonseed, hulls, and burrs [3]. This trash is rich in nitrogen, phosphorus, potassium and other micronutrients that can be added to soil for plant growth. However, it cannot be re-used directly as a soil amendment due to the presence of $22 \%$ permanganate lignin, which delays its decomposition rate [2].

Some of the options for utilizing the large biomass of cotton waste include gasification, pyrolysis, composting, fermentation, and anaerobic digestion. [4]. Composting is a costeffective and environmentally friendly way of turning trash into a stable, nutrient-rich substance [5]. Composting cotton gin trash can assist in reducing dry matter and volume [6]. Gasification is a high temperature thermochemical process that transforms carbonaceous materials into synthesis gas and biochar with low calorific value [7]. The gas can be used to power the gas engines, coupled with generators to generate on-site electrical power [8]. It is well documented that biochar improves the biological and physical properties of soil by providing a habitat to microbes and by improving water holding capacity; however, its impact on crop yield is mostly dependent on the availability of a nitrogen source [9]. 
Fischer and Glaser [10] have demonstrated a synergistic effect between biochar and the composting process, and proposed that biochar with compost use as soil supplement enhances nitrogen utilization efficiency and prevents nitrogen immobilization. For the past decade, adding biochar as a feedstock during composting has attracted a lot of interest with regard to preparing high-quality compost $[10,11]$. However, its usage in soil for agronomic purposes has received little attention. Biochar is used in the composting process to reduce nitrogen and organic carbon losses, to reduce heat and GHG emissions, and to decrease the composting period [10]. It also helps to reduce odor, improve aeration, and provide more oxygen [11], which not only accelerates the rate of decomposition by boosting the microbial activity [12], but also maintains a larger population of beneficial microbes. Co-composting is one of the most effective strategies for hastening the composting process and results in a finished product with higher fertility and carbon sequestration potential.

This is the first study of using both thermal and biological decomposition means to value cotton gin trash in order to prepare products for soil application. In this study, cotton gin trash was valorized for soil application by preparing biochar (BC), compost $(\mathrm{C})$ and co-compost of biochar (Coc). Another objective was to grow some test plants in order to see if these thermally and biologically transformed products could be used as organic additives in soil. The main goal of this research was to improve the structure, function, and health of soil while also lowering the expenses of commercial inorganic fertilizers routinely used in crop production.

\section{Methodology}

\subsection{Characterization of Feedstock}

Cotton gin trash was gathered from Varisco Cotton Gin, Brazos County, Texas, USA. After air drying, it was ground to a particle size of $\sim 2 \mathrm{~mm}$ using Wiley Laboratory Mill Model \#4, USA. Scrap of fruit and vegetable were obtained from local fruit and vegetable shops and used in the same collected condition.

Characteristics of feedstock have been listed in Table 1. Percent C, H, N and S content of the feedstock was determined through an elemental analyzing system $(\mathrm{GmbH}$, Vario MICRO cube V1.9.4). Calorific value was measured using Parr Isoperibol Bomb Calorimeter (Model 6200, Parr Instrument Company, Moline, IL, USA). Volatile content was determined through loss in weight at $900{ }^{\circ} \mathrm{C}$ for 6 min [13]. Ash content was measured by finding the weight loss, after $6 \mathrm{~h}$ at $750^{\circ} \mathrm{C}$ in muffle furnace [14].

Table 1. Variation in the characteristics of cotton gin trash used as feedstock.

\begin{tabular}{ccccc}
\hline \multirow{2}{*}{ Feedstocks } & \multicolumn{4}{c}{ Proximate Analysis } \\
\cline { 2 - 5 } & $\begin{array}{c}\text { Moisture } \\
\text { Content (\%) }\end{array}$ & Ash (\%) & $\begin{array}{c}\text { Volatile } \\
\text { Content (\%) }\end{array}$ & $\begin{array}{c}\text { Calorific Value } \\
\mathbf{( M J ~ k g ~}^{-1} \text { ) }\end{array}$ \\
\hline CGT & $11.50 \pm 0.46$ & $7.2 \pm 0.68$ & $68.7 \pm 0.52$ & $17.99 \pm 0.07$ \\
\hline FVS & $75.00 \pm 3.0$ & $5.63 \pm 0.57$ & $53.75 \pm 0.73$ & $13.29 \pm 0.60$ \\
\hline & $\mathbf{C}$ & Ultimate Analysis (\%) & \\
\hline CGT & $40.09 \pm 0.32$ & H & $\mathbf{N}$ & $\mathbf{S}$ \\
\hline FVS & $40.88 \pm 0.5$ & $5.25 \pm 0.4$ & $1.48 \pm 0.3$ & $2.76 \pm 0.4$ \\
\hline
\end{tabular}

Here: CGT: Cotton gin trash, FVS: Fruit and vegetable scrap, C: carbon, H: hydrogen, N: nitrogen, S: sulfur Analysis have been carried out on dry basis.

\subsection{Preparation of Biochar}

Cotton gin trash biochar was prepared through a gasification process at a temperature of $760{ }^{\circ} \mathrm{C}$ by using a mobile fluidized bed gasifier developed at Texas A\&M University (Parnell and LePori, 1988; Patent No. 4848249) for 30 mins with a feeding rate of $70 \mathrm{~kg} \mathrm{~h}^{-1}$ and $2.5 \mathrm{lbs} \mathrm{min}^{-1}$ pressure. On cooling, the biochar was stored in zip lock bags until further use. 


\subsection{Preparation of Compost and Co-Compost}

The compost pile was made by combining fruit and vegetable scrap (wet basis) with dried powdered cotton gin trash (ratio $3: 1 \mathrm{~kg} \mathrm{w/w}$ ) which provided $59 \%$ moisture and 30:1 C/ $\mathrm{N}$ ratio equal to the recommended value for composting reported in literature [15]. The pile initial $\mathrm{pH}$ was 6.6. For co-composting, fruit and vegetable scrap (wet basis) was mixed with $20 \%$ dry cotton gin trash biochar (ratio 5:1 $\mathrm{kg} \mathrm{w} / w$ as per the literature [16] resulting in a moisture content of $50 \%$ and a $\mathrm{C} / \mathrm{N}$ ratio of $28: 1$. The mixture was put in tumblers (57 gallons capacity; Figure S1) and composted for eight weeks (May-June, ambient temperature around $39^{\circ} \mathrm{C}$ ). The tumblers were turned on a regular basis to ensure mixing, homogenization and aeration in order to stimulate the activity of microbes. The moisture level of the pile was monitored periodically and kept at $50-60 \%$ by adding water as needed. After the composting period, the sample was air dried, ground and stored in zip lock bags at room temperature for further use.

\subsection{Characterization of Thermal and Biological Products}

Biochar, compost and co-compost were physico-chemically characterized. The $\mathrm{pH}$ and EC of biochar and co-compost were determined by preparing water extract in a ratio of 1:20 in deionized water [17] and for compost in a ratio of 1:5, by using a mechanical shaker for $3 \mathrm{~h}$. Ultimate analyses as well as calorific value, volatile and ash content were determined as described in Section 2.1. Fixed carbon was calculated by using the following equation:

$$
\text { Fixed carbon }=100-[(\text { Moisture })+(\text { Volatile })+(\text { ash })] .
$$

Total oxygen was measured by subtracting the percentages of all elements and ash from 100 [14]. The organic matter content of the compost was calculated by the procedure given by Trautmann and Krasny [15], which consisted of placing the sample in a muffle furnace at $500{ }^{\circ} \mathrm{C}$ for $16 \mathrm{~h}$. The specific surface area (BET) was determined by using $0.12 \mathrm{~g}$ of sample. The sample was outgassed to 20 microns at $110^{\circ} \mathrm{C}$, keeping the testing temperature at $-195.76^{\circ} \mathrm{C}, \mathrm{N}_{2}$ gas adsorption/desorption was performed at $77 \mathrm{~K}$ over the relative pressure range of $\mathrm{P} / \mathrm{P} 0=0.05-0.30$. The functional groups of the samples were determined using a Fourier Transform Infrared Spectrophotometer (Shimadzu IRAffinity-1). The sample was scanned in the wavelength range of $600-3900 \mathrm{~cm}^{-1}$. The thermal stability of biochar was determined by performing thermogravimetric analysis (SDT Q600, TA instruments). The measurements were taken from ambient temperature to $850{ }^{\circ} \mathrm{C}$ with $100 \mathrm{~mL} \mathrm{~min}{ }^{-1}$ nitrogen gas flow rate and $20^{\circ} \mathrm{C} \mathrm{min}-1$ heating rate. The non-combustible fraction was calculated as the weight left after thermal combustion relative to the initial weight of biochar.

\subsection{Greenhouse Experiment}

The effect of applying biochar, compost, and co-compost on plant growth traits as well as soil characteristics was investigated in a greenhouse experiment. Pots having a capacity of $1.5 \mathrm{~kg}$ soil were used in the experiment (Figure S2). In the soil, amendments were applied at rates of $2.5 \mathrm{t} \mathrm{ha}^{-1}, 5 \mathrm{t} \mathrm{ha}^{-1}$ and $10 \mathrm{tha}^{-1}$. The soil was amended with respective amounts of $\mathrm{BC}, \mathrm{C}$ and $\mathrm{Coc}$ and left for two weeks for incubation. Three seeds of salad radish var. cherry belle (Raphanus raphanistrum) were sown in each pot and after ten days one healthiest plant (on the basis of visual appearance) was retained. Triplicates were grown for each soil treatment. Plants were harvested after 28 days and properties of post harvested soil were determined. Plant growth parameters such as number of leaves, leaf area, plant height, root length and chlorophyll content were also determined.

\subsection{Statistical Analysis}

Data were summarized by applying the descriptive statistics viz. means and standard deviation based on three replicates for each variable, using Microsoft Office Excel (version, 2010) XL Stat Add In. $\mathrm{LSD}_{0.05}$ was computed to compare the mean differences among the treatments. 


\section{Results and Discussion}

\subsection{Characteristics of Biochar, Compost and Co-Compost}

The biochar yield was $15 \%$, and thermogravimetric examination of cotton gin trash biochar revealed that it was far more stable as only $20 \%$ loss in mass was observed on heating to $850^{\circ} \mathrm{C}$ (Figure 1 ).

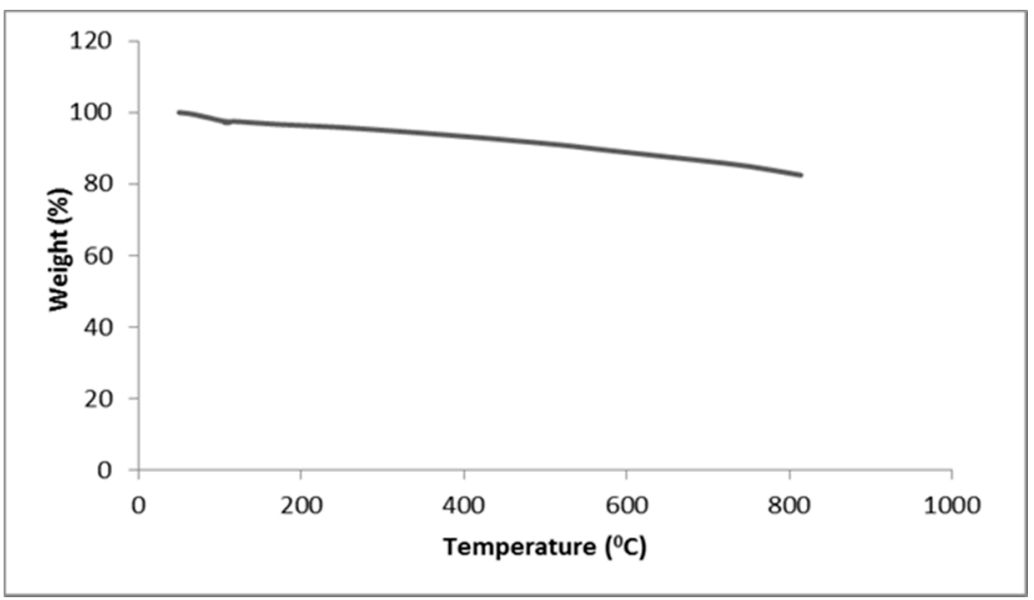

Figure 1. Thermogravimetric analysis (TGA) of cotton gin trash biochar.

Brewer et al. [18] also observed less biochar yield from gasification as compared to other pyrolysis processes, which might be due to more oxidation of the carbon into carbon monoxide, resulting in a large yield of syngas. The physico-chemical parameters of the prepared products from cotton gin trash have been given in Table 2. Almost all parameters of co-compost showed intermediate characteristics between biochar and compost. The color of biochar and co-compost of biochar were black as compared to compost that was brown. The bulk density of the compost and co-compost was much higher as compared to that of biochar. Volatile content of biochar $15.09 \%$ was low whereas ash content $78.75 \%$ was high as compared to raw cotton gin trash. Cao and Harris [19] observed that ash content rises with increase in pyrolysis temperature, possibly due to increase in mineral concentration and organic combustion residues. Previous studies have shown that biochar produced by gasification contains more ash than biochar produced from pyrolysis due to the loss of more volatile materials $[18,19]$. High ash content observed in co-compost while as expected, it was the lowest in compost.

On comparing surface area, biochar $\left(5.67 \mathrm{~m}^{2} \mathrm{~g}^{-1}\right)$ and co-compost $\left(4.25 \mathrm{~m}^{2} \mathrm{~g}^{-1}\right)$ had higher values as compared to compost $\left(1.23 \mathrm{~m}^{2} \mathrm{~g}^{-1}\right)$. A high surface area of co-compost might be due to the presence of biochar, which provides porosity and aids in reducing bulk density [20]. Hansen et al. [21] suggested that high processing temperature is the responsible factor for high surface area of biochar. According to Pacioni et al. [22], high volatile contents in the feedstock are responsible for the high porous structure of biochar. The removal of deposited material from the biochar surface after contact with water caused the surface area to rise in addition of biochar to the soil. Organic materials and soil microorganisms may subsequently become lodged in the pores. 
Table 2. Characteristics of biochar, compost and co-compost prepared from cotton gin trash.

\begin{tabular}{|c|c|c|c|}
\hline Physico-Chemical Parameters & Biochar (BC) & Compost (C) & Co-Compost (Coc) \\
\hline Colour & Black & Dark brown & Black \\
\hline Bulk Density $\left(\mathrm{g} \mathrm{m}^{-3}\right)$ & $0.516 \pm 0.03$ & $615 \pm 0.4$ & $452 \pm 2.2$ \\
\hline Specific Surface Area $\left(\mathrm{m}^{2} \mathrm{~g}^{-1}\right)$ & $5.67 \pm 0.2$ & $1.23 \pm 0.04$ & $4.25 \pm 0.2$ \\
\hline $\mathrm{pH}$ & $\begin{array}{c}10.40 \pm 0.3 \\
(1: 20)\end{array}$ & $\begin{array}{l}8.20 \pm 0.3 \\
\quad(1: 5)\end{array}$ & $\begin{array}{c}10.42 \pm 0.5 \\
(1: 20)\end{array}$ \\
\hline $\begin{array}{l}\text { Electrical Conductivity } \\
\qquad\left(\mu \mathrm{S} \mathrm{cm}^{-1}\right)\end{array}$ & $2763 \pm 153$ & $1280 \pm 31$ & $1473 \pm 45$ \\
\hline $\begin{array}{l}\text { Cation exchange capacity } \\
\qquad\left(\mathrm{cmol}_{\mathrm{c}} \mathrm{kg}^{-1}\right)\end{array}$ & $157.9 \pm 4.9$ & $44.3 \pm 2.9$ & $89.3 \pm 5.3$ \\
\hline Calorific Value (MJ kg ${ }^{-1}$ ) & $3.97 \pm 0.5$ & $12.23 \pm 0.3$ & $13.57 \pm 0.25$ \\
\hline Volatile Content $(\%)$ & $15.09 \pm 0.27$ & - & - \\
\hline Ash Content (\%) & $78.75 \pm 2.12$ & $35.20 \pm 3.2$ & $60.70 \pm 4.3$ \\
\hline Fixed Carbon (\%) & $3.66 \pm 0.15$ & - & - \\
\hline \multicolumn{4}{|c|}{ Elemental composition } \\
\hline $\mathrm{C}(\%)$ & $18.69 \pm 0.4$ & $36.2 \pm 0.4$ & $29.79 \pm 0.6$ \\
\hline $\mathrm{H}(\%)$ & $0.70 \pm 0.03$ & $4.85 \pm 0.02$ & $3.73 \pm 0.05$ \\
\hline $\mathrm{N}(\%)$ & $0.66 \pm 0.02$ & $2.24 \pm 0.02$ & $1.97 \pm 0.2$ \\
\hline $\mathrm{S}(\%)$ & $0.21 \pm 0.01$ & $0.33 \pm 0.01$ & $0.57 \pm 0.03$ \\
\hline $\mathrm{O}(\%)$ & $0.99 \pm 0.02$ & $56.30 \pm 0.02$ & $63.9 \pm 0.1$ \\
\hline $\mathrm{H} / \mathrm{C}$ ratio & $0.44 \pm 0.01$ & $1.59 \pm 0.2$ & $1.49 \pm 0.03$ \\
\hline $\mathrm{O} / \mathrm{C}$ ratio & $0.04 \pm 0.001$ & $1.17 \pm 0.1$ & $1.61 \pm 0.2$ \\
\hline $\mathrm{C} / \mathrm{N}$ ratio & $33.20 \pm 0.74$ & $16.20 \pm 0.34$ & $15.12 \pm 0.62$ \\
\hline$(\mathrm{O}+\mathrm{N}) / \mathrm{C}$ ratio & $0.072 \pm 0.002$ & 1.214 & 1.67 \\
\hline
\end{tabular}

In comparison to the feedstock, biochar had a low carbon and hydrogen content. Yu et al. [23] and Brewer et al. [24] reported lesser carbon content in biochar prepared through gasification due to the presence of more condensed aromatic rings. More carbon $(29.79 \%)$ and nitrogen (1.97\%) were observed in co-compost as compared to sole biochar (C: $18.69 \%$ and N: 18.69\%). Sánchez-García et al. [25] observed about 70\% retention of inorganic nitrogen in biochar-compost after adding the biochar as a bulking agent and reported positive impact of composted biochar on growth of plants and properties of soil. Compared to the pile, the decrease in $\mathrm{C} / \mathrm{N}$ ration in compost and co-compost, as observed in this study, is due to the stabilization of organic matter [26]. In comparison to the feedstock, a drop in $\mathrm{C} / \mathrm{N}$ ratio was also observed during composting in compost and cocompost in this study. On the other hand, $\mathrm{H} / \mathrm{C}$ ratio estimates the aromaticity while $\mathrm{O} / \mathrm{C}$ evaluates the degree of oxidation and stability of the biochar [27] and $(\mathrm{O}+\mathrm{N}) / \mathrm{C}$ estimates the polarity of the biochar, which is significantly affected by the pyrolysis temperature. Abdulrazzaq et al. [28] stated that biochar prepared through gasification generally has a higher degree of aromaticity as compared to biochar prepared through pyrolysis. A high degree of aromaticity also indicates biochar stability in the environment [29]. Therefore, cotton gin trash biochar can be a good and stable amendment for soil application.

Scanning electron micrographs of the prepared biochar, compost and co-compost are presented in Figure 2. Surface morphology of the biochar was observed to be heterogeneous, having pores and channels. Deposition of inorganic materials was also observed that appeared to have blocked the surface of pores. Brewer et al. [18] reported that high mineral content of CGT biochar makes it a good substrate to improve organic matter of the soil. The surface morphology of compost and co-compost showed smaller fragments with 
morphological heterogeneity. Fungal hyphae and broken mycelia were also observed in the compost and co-compost due to the presence of greater microbial content.
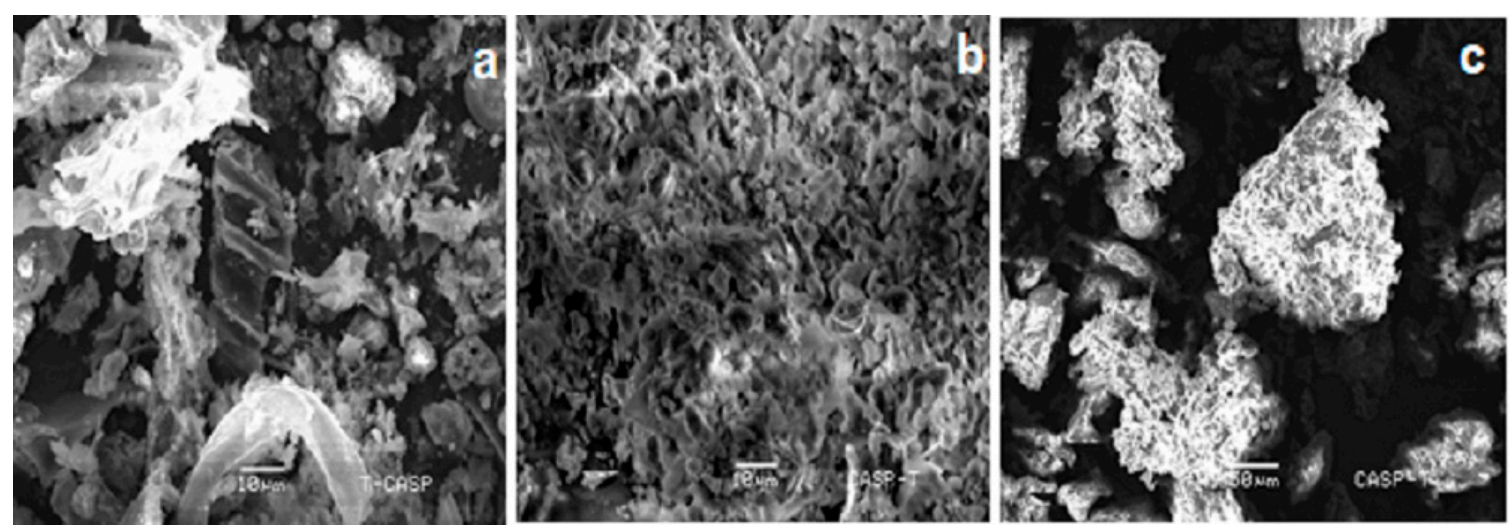

Figure 2. Scanning electron micrographs (a) cotton gin trash biochar, (b) compost (c) co-composted biochar.

FTIR spectra of cotton gin trash feedstock and biochar are shown in Figure 3. In feedstock spectra, peak around 1300 and $1500 \mathrm{~cm}^{-1}$ in feedstock spectra indicate the presence of lignin, while the highest peak around $1000 \mathrm{~cm}^{-1}$ is associated with the presence of cellulose. The peak around $3300 \mathrm{~cm}^{-1}$ in the biochar sample corresponds to $\mathrm{O}-\mathrm{H}$ stretching [30], whereas this peak was not visible in the feedstock sample.

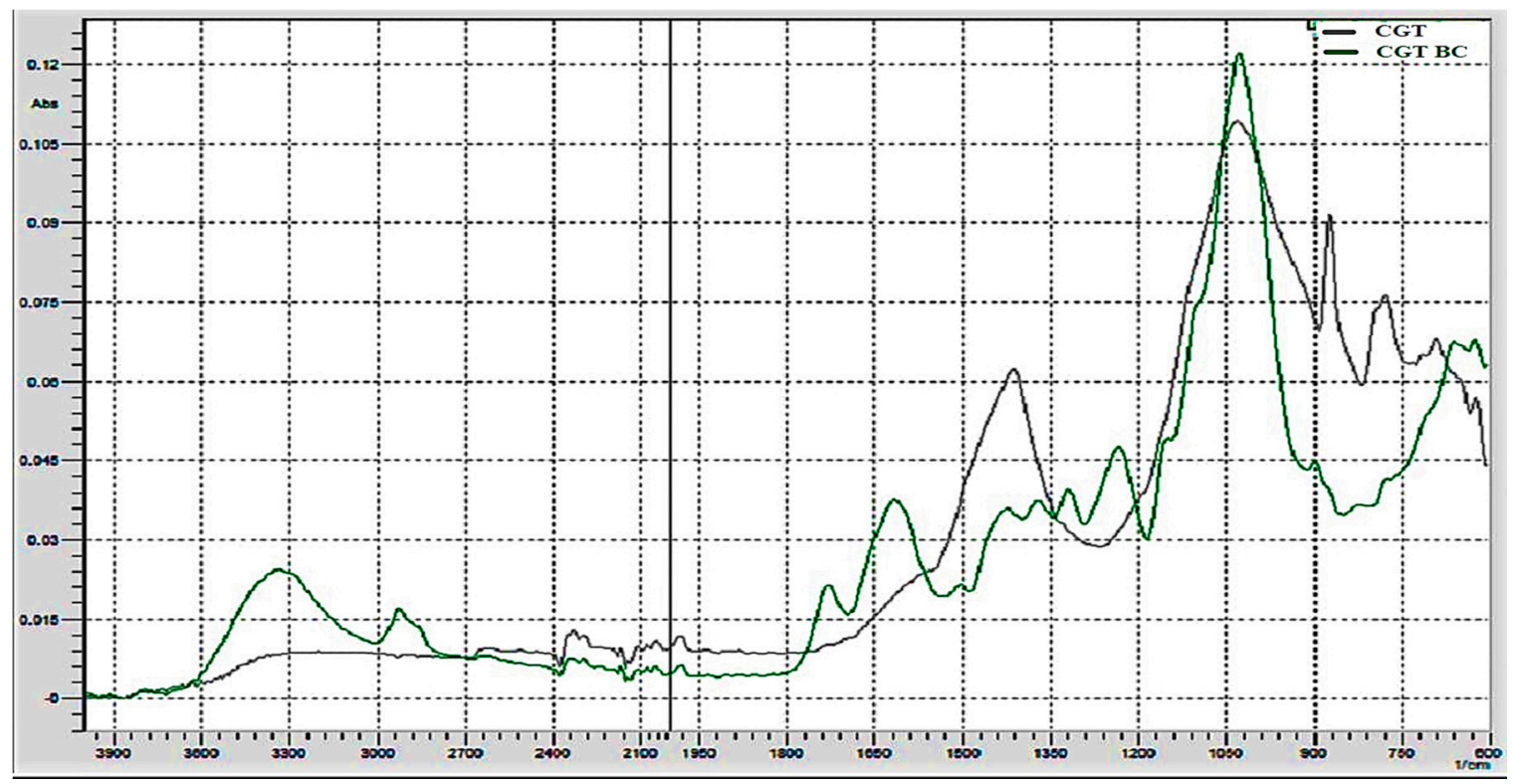

Figure 3. FTIR spectra of cotton gin trash and its biochar.

The peak around $2880 \mathrm{~cm}^{-1}$ corresponded to asymmetric and symmetric C-H stretching vibrations for aliphatic groups; at $1710 \mathrm{~cm}^{-1}$ it is related to carboxyl $\mathrm{C}=\mathrm{O}$ stretching, while at $1620 \mathrm{~cm}^{-1}$ it corresponds to aromatic $\mathrm{C}=\mathrm{C}$ stretching and $\mathrm{C}=\mathrm{O}$ stretching of ketones and quinones. Peaks around $1440 \mathrm{~cm}^{-1}$ and $1380 \mathrm{~cm}^{-1}$ are related to the C-C stretching vibrations in the aromatic ring while the peak around $1280 \mathrm{~cm}^{-1}$ in biomass corresponds to ester carbonyls, $\mathrm{C}=\mathrm{O}$ and related to hemicellulose that diminishes during pyrolysis. The peak around $990 \mathrm{~cm}^{-1}$ in biomass which is related to cellulose content, is not visible in the biochar sample. Xue et al. [31] reported that aromatic groups and oxygen rich functional groups in gasification biochar such as $\mathrm{C}-\mathrm{O}$ and $\mathrm{C}=\mathrm{O}$ provide strong active sites and help in increasing the adsorption capacity of the biochar. The FTIR spectra of the compost (Figure 4) and co-compost (Figure 5) are somewhat similar but are very 
much different from the feedstock and biochar spectra. The peak at $2975 \mathrm{~cm}^{-1}$ in compost and in co-compost showed $\mathrm{C} \equiv \mathrm{N}$ nitrile and $\mathrm{C}=\mathrm{O}$ stretch or presence of carboxylic acids, aldehydes and ketones. The peak around $1369 \mathrm{~cm}^{-1}$ could be attributed to the $\mathrm{C}-\mathrm{H}$ band of alkanes, and that around $1000 \mathrm{~cm}^{-1}$ showed the C-O-C group and polysaccharides in the compost [32]. Thies and Rillig, [33] reported an increase in reactivity of surfaces of biochar with composting and, according to Steiner et al. [34], increased moisture absorption of biochar-amended composts has greater beneficial effects on the composting process. Schulz et al. [35] suggested that co-composting is an effective way to overcome the nutrient deficiency of biochar.

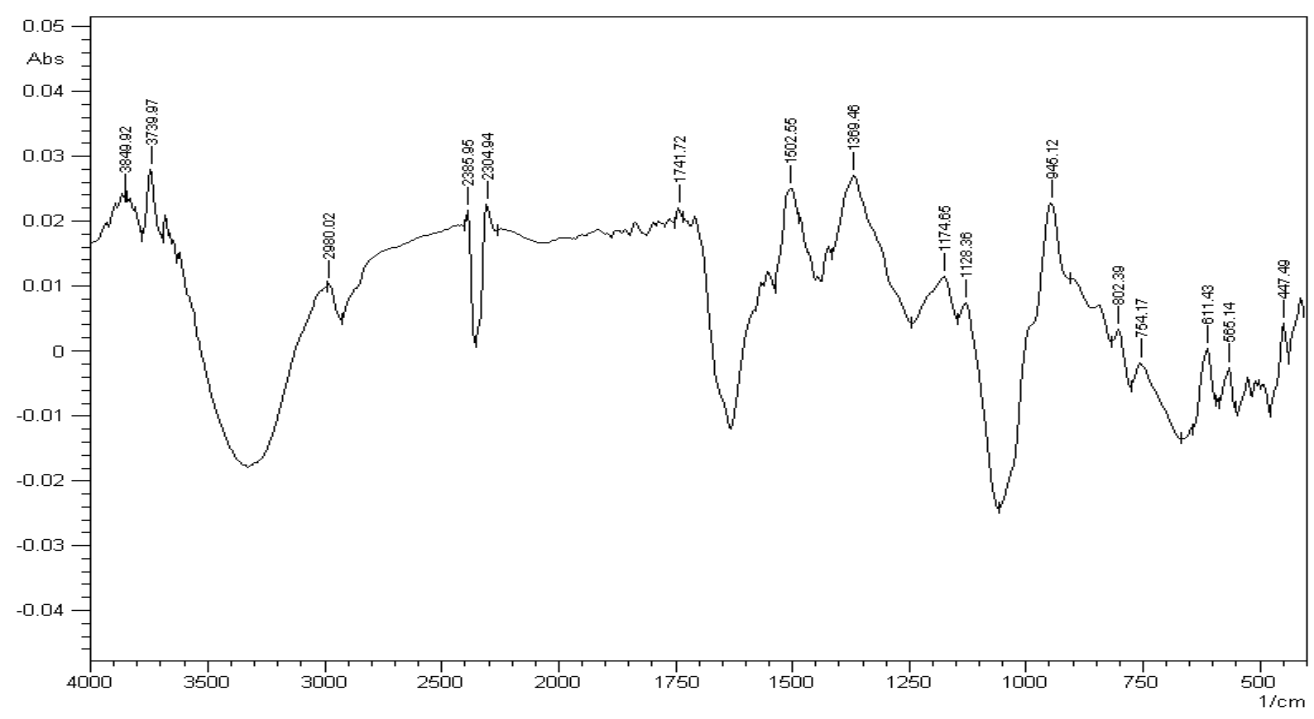

Figure 4. FTIR spectra of cotton gin trash compost.

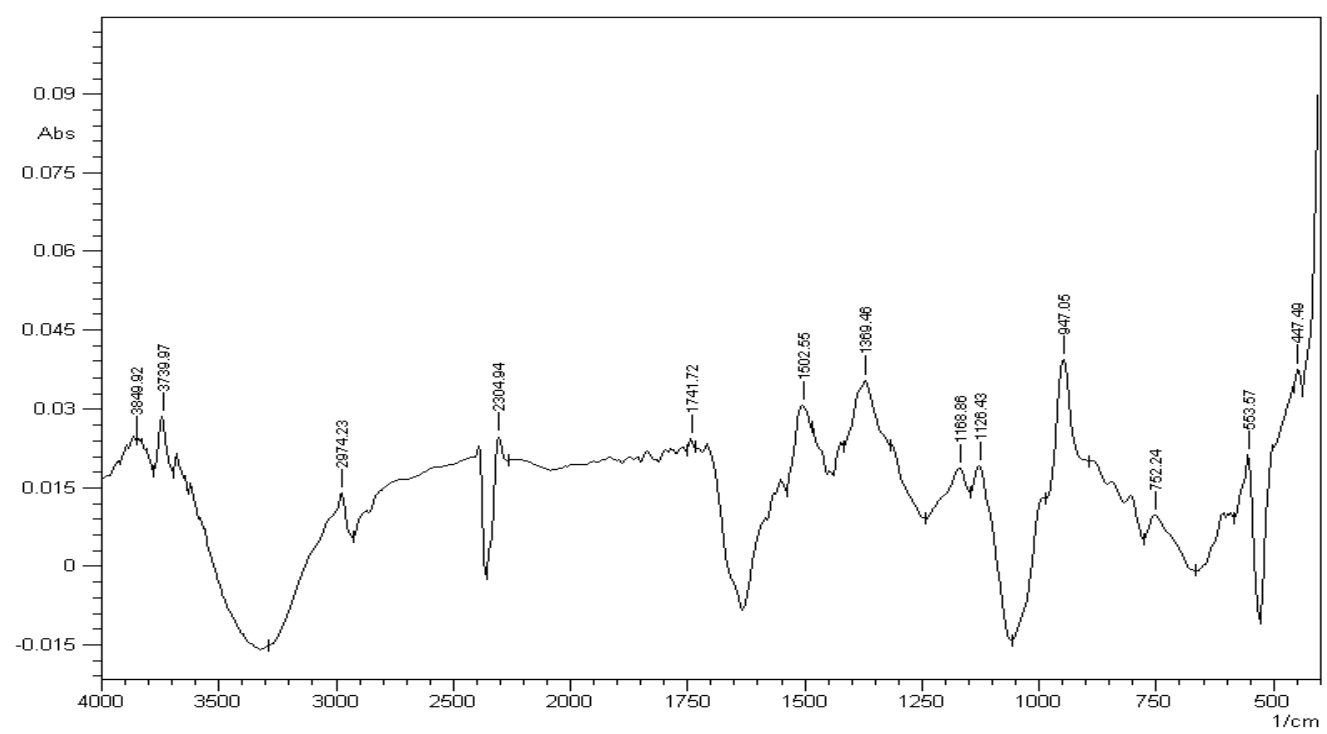

Figure 5. FTIR spectra of cotton gin trash co compost.

\subsection{Effect of Soil Amendments on Growth of Plants}

The results of the greenhouse growth experiment (Figure S3) with salad radish have been presented in Figure 6. The maximum number of leaves were observed in plants growing in co-compost $\left(2.5 \mathrm{t} \mathrm{ha}^{-1}\right)$. The highest leaf area, $116 \mathrm{~cm}^{2}$, was observed in the treatment $\operatorname{Coc}\left(5 \mathrm{t} \mathrm{ha}^{-1}\right)$, followed by $110 \mathrm{~cm}^{2}$ and $97.56 \mathrm{~cm}^{2}$ in $B C$ and $C$ respectively. The lowest plant length was observed in the control, being significantly different than other treatments. 

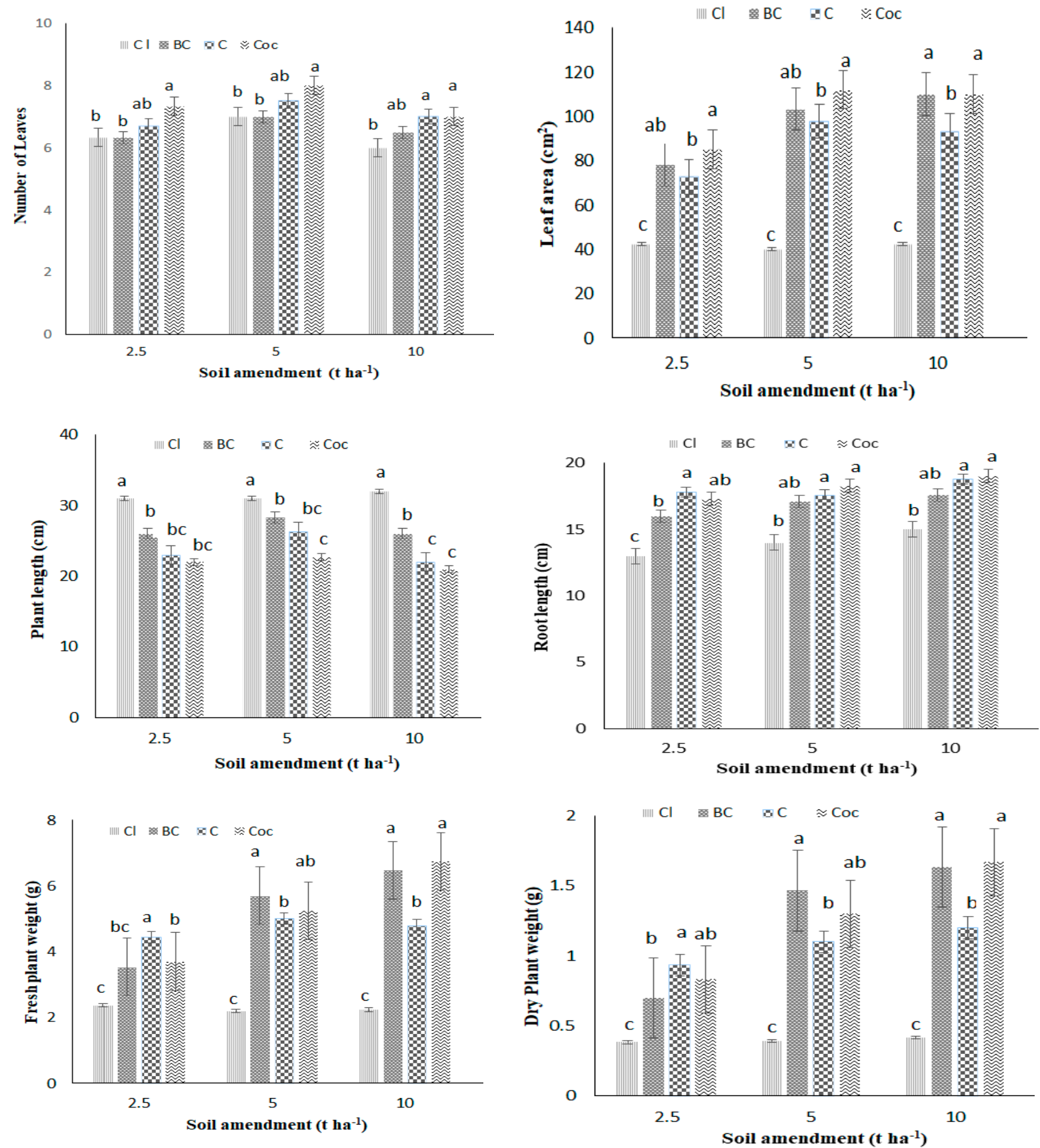

Figure 6. Effect of different amendment rates of biochar, compost and co-compost on some growth parameters of Raphanus sativus. The mean \pm S.D. values followed by different letters $(a, b, c)$ are significantly different according the Least Significant Different $\left(\mathrm{LSD}_{0.05}\right)$ test.

The control treatment encouraged a rise in the plant's above-ground portion while inhibiting its underground edible portion. The maximum root length (edible part) was $19.3 \mathrm{~cm}$ in $\mathrm{C}\left(2.5 \mathrm{t} \mathrm{ha}^{-1}\right)$ followed by $18 \mathrm{~cm}$ in co-compost $\left(2.5\right.$ and $\left.10 \mathrm{t} \mathrm{ha}^{-1}\right)$, demonstrating that increasing the amendment rate did not significantly boost plant output. In the present study, $\operatorname{Coc}\left(10 \mathrm{t} \mathrm{ha}^{-1}\right)$ has resulted in increasing the biomass yield to $315 \%$ as compared to the control. It might be due to the reason that Coc was more nutrient enriched as compared to other treatments. Tejada and Gonzalez [36] reported a 5\% increase in rice yield after applying cotton gin trash compost in soil, whereas by amending $2 \%$ co-composted biochar, Kammann et al. [37] reported a 305\% increase in the biomass yield of Chenopodium quinoa. Darby et al. [38], also observed an almost similar 309\% rise in the biomass of Sesbania sesban by using $1.5 \%$ co-composted biochar. 
The addition of organic amendments increased the average leaf chlorophyll by 20 to 30\% (Figure 7), Agegnehu et al. [39], also reported that organic treatments had considerably improved average leaf chlorophyll by 4.2 to $5.7 \%$ in maize during the crop growth phase.

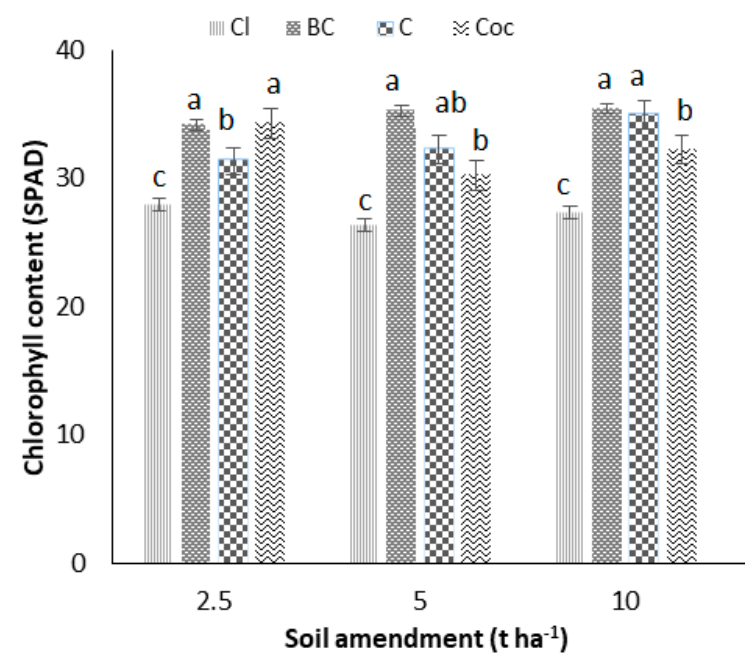

Figure 7. Effect of different amendment rates of biochar, compost and co-compost on the chlorophyll content of Raphanus sativus. The mean \pm S.D. values followed by different letters $(a, b, c)$ are significantly different according the Least Significant Different $\left(\mathrm{LSD}_{0.05}\right)$ test.

The addition of compost or co-compost in soil produced healthier plants, explaining the higher biomass and yield.

Papafotiou et al. [40] reported that cotton gin trash compost can replace peat along with perlite in the growing medium of flowering plants without having any negative effects on plant growth. In this study, the role of Coc has been suggested to compensate fertilizer application.

\subsection{Post-Harvest Soil Analysis}

Analysis of the post harvested soil is shown in Figure 8. These amendments showed promising results in increasing the soil organic matter and greater increase in SOM was observed by increasing the amendment rate. The maximum increase in SOM (8.1\%) was observed in Coc $\left(10 \mathrm{t} \mathrm{ha}^{-1}\right)$, followed by $7.8 \%$ in BC $\left(10 \mathrm{t} \mathrm{ha}^{-1}\right)$ as compared to control (4.3\%). Similar to this, Zhang [41] reported an increase in soil organic matter by using cotton gin trash biochar. Oldfield et al. [42] observed a long-term carbon sequestration in soil on adding biochar and co-composted biochar. Yuan et al. [43] found improvement in soil organic carbon by the application of manure compost and biochar manure compost in a short-term incubation period. Díaz et al. [44] reported an enhanced level of organic matter by the co-composting of vinasse with cotton gin trash. The addition of organic amendment resulted in an increase in conductivity from $16 \mathrm{mS} \mathrm{cm}^{-1}$ to $22 \mathrm{mS} \mathrm{cm}^{-1}$ in Coc (10 t/ha). An increase in $\mathrm{pH}$ from 7.7 to 8.4 was observed in Coc (10 t/ha). The addition of organic amendment has also resulted in reducing soil bulk density and the maximum was observed in Coc and C (10 t ha $\left.{ }^{-1}\right)$, which resulted in increasing root length. Therefore, the addition of biochar or co-composted biochar not only adds organic matter to soil but also ensures better soil health, promoting growth as well as reducing fertilizer cost. 

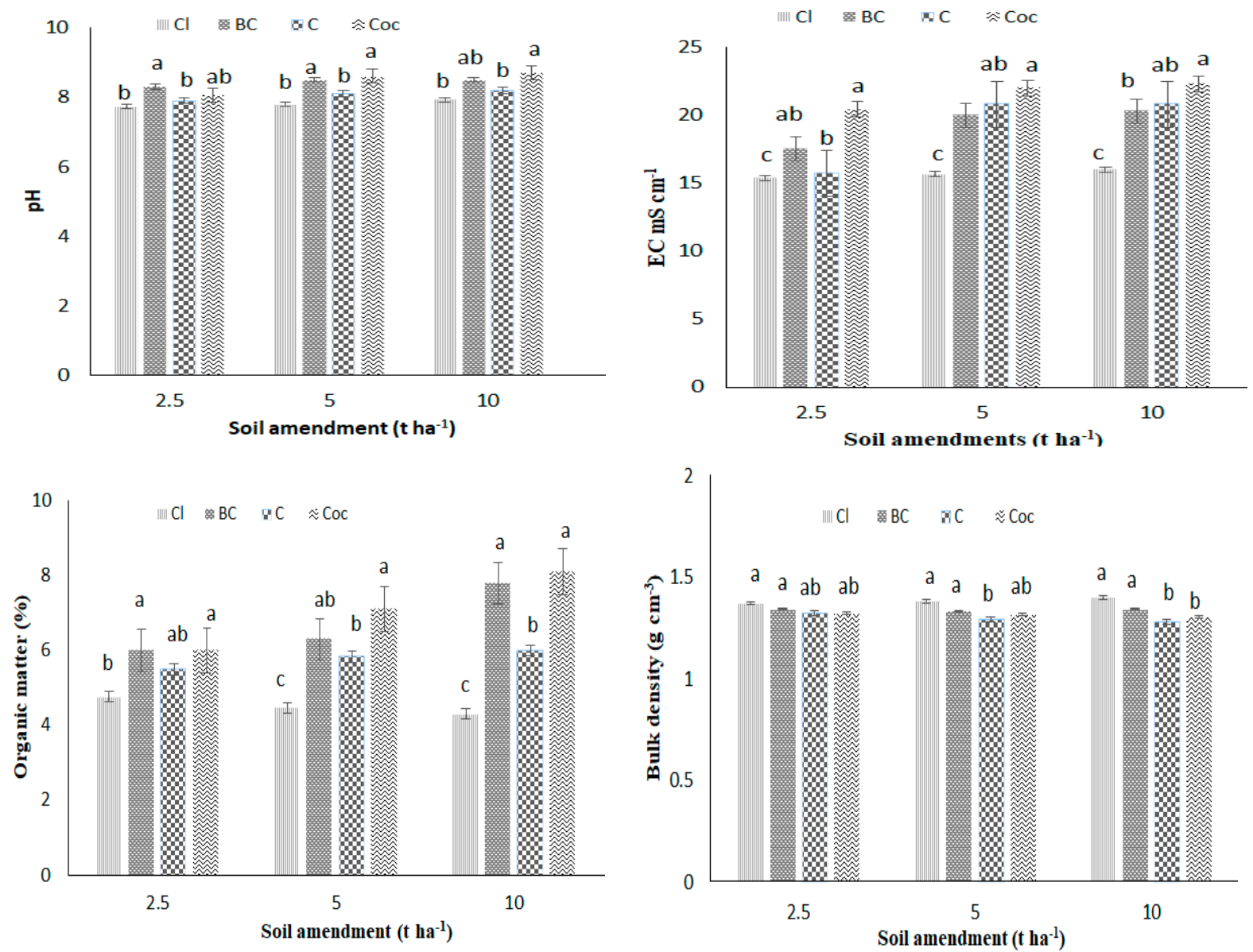

Figure 8. Changes in characteristics of soil having different amendment rates of biochar, compost and co-compost after harvesting Raphanus sativus. The mean \pm S.D. values followed by different letters $(\mathrm{a}, \mathrm{b}, \mathrm{c})$ are significantly different according the Least Significant Different $\left(\operatorname{LSD}_{0.05}\right)$ test.

\section{Conclusions}

This study concludes that cotton gin trash can be successfully managed in an environmentally friendly and economically beneficial manner by converting it into biochar, compost, and co-composted derivatives, all of which can be used as high-quality soil conditioners. The biochar-based management of cotton gin trash not only eliminates its negative impacts on the environment but also brings benefits in the form of low-cost organic fertilizers. The application of the co-composted derivative of cotton gin trash had significantly improved physical, chemical and biological properties of soil e.g., the soil organic matter increased from $4.4 \%$ to $7.9 \%$ and plant biomass was up to $31.5 \%$ more than control., The valorization of cotton gin trash through derivation of organic amendments is a sustainable solution for management of such kinds of wasted biomass.

Supplementary Materials: The following are available online at https: / www.mdpi.com/article/10 .3390 / su132413842/s1, Figure S1: In vessel composting system for compst and co-compost preparation, actual and schematic representation; Figure S2: Pot experiment; Figure S3: Plant agronomic characters.

Author Contributions: Conceptualization, Q.-u.-A., A.N. and M.S.; methodology, Q.-u.-A., A.N. and M.S.; validation, S.C.C. and M.S.; formal analysis, Q.-u.-A. and S.C.C.; investigation, M.S. and F.-e.-B., resources, Q.-u.-A., A.N., S.C.C., M.S. and F.-e.-B.; data curation, Q.-u.-A. and M.S.; writing, original draft preparation, Q.-u.-A. and A.N.; writing, review and editing, Q.-u.-A., A.N. and M.S.; supervision, S.C.C., M.S. and F.-e.-B.; funding acquisition, Q.-u.-A., A.N., S.C.C., M.S. and F.-e.-B. All authors have read and agreed to the published version of the manuscript. 
Funding: Except part of this study funded by Higher Education Commission (HEC), Pakistan, on providing financial support through a PhD grant (HEC/FD/2013-2015) for indigenous 5000 scholars; the current study received no funding from any external source.

Institutional Review Board Statement: Not applicable.

Informed Consent Statement: Not applicable.

Data Availability Statement: Not applicable.

Acknowledgments: We acknowledge Higher Education Commission (HEC), Pakistan, on providing financial support through a PhD grant (HEC/FD/2013-2015) for indigenous 5000 scholars.

Conflicts of Interest: The authors declare no conflict of interest. This manuscript has no associated data set.

\section{References}

1. OECD-FAO. Agricultural Outlook 2019-2028; OECD Publishing: Paris, France, 2019. [CrossRef]

2. Hamawand, I.; Sandell, G.; Pittaway, P.; Chakrabarty, S.; Yusaf, T.; Chen, G.; Seneweera, S.; Al-Lwayzy, S.; Bennett, J.; Hopf, J. Bioenergy from cotton industry wastes: A review and potential. Renew. Sustain. Energy Rev. 2016, 66, 435-448. [CrossRef]

3. Sollenberger, L.E.; Reis, R.A.; Nussio, L.G.; Chambliss, C.G.; Kunkle, W.E. Conserved forage. In Warm-Season (C4) Grasses. Agronomy Monograph; More, L.E., Burson, B.L., Sollenberger, L.E., Eds.; Agronomy Journal: Madison, WI, USA, 2012; Volume 45, pp. 355-387. [CrossRef]

4. Ismail, Z.Z.; Talib, A.R. Recycled medical cotton industry waste as a source of biogas recovery. J. Clean. Prod. 2016, 112, 4413-4418. [CrossRef]

5. Fava, A. The "waste" with 2.5 million tons of potential. In Business-Emmaus Pennsylvania; Auburn University: Auburn, AL, USA, 2004; Volume 26, pp. 26-27.

6. Mayfield, W. Gin trash utilization: What are the options? In Proceedings-Beltwide Cotton Conferences; National Agricultural Library: Beltsville, MD, USA, 1992; pp. 496-497.

7. Higman, C.; van der Burgt, M. Gasification, 2nd ed.; Gulf Professional Publishing: Oxford, UK, 2008.

8. Liu, X.; Farmer, M.; Capareda, S.; Schmitz, A.; Wilson, N.; Moss, C.; Zilberman, D. The Economic Feasibility of Electricity Generation from Biomass on the South Plains of Texas. In The Economics of Alternative Energy Sources and Globalization; Schmitz, A., Wilson, N., Moss, C., Bentham, D.Z., Eds.; Bentham eBooks: Anna Paulownalaan, The Netherlands, 2011; pp. $158-169$.

9. Wang, Y.; Villamil, M.B.; Davidson, P.C.; Akdeniz, N. A quantitative understanding of the role of co-composted biochar in plant growth using meta-analysis. Sci. Total Environ. 2019, 685, 741-752. [CrossRef]

10. Fischer, D.; Glaser, B. Synergisms between compost and biochar for sustainable soil amelioration. In Management of Organic Waste; Sunil, K., Bharti, A., Eds.; InTech: Rijeka, Croatia, 2012; pp. 167-198.

11. Agyarko-Mintah, E.; Cowie, A.; Singh, B.P.; Joseph, S.; Van Zwieten, L.; Cowie, A.; Harden, S.; Smillie, R. Biochar increases nitrogen retention and lowers greenhouse gas emissions when added to composting poultry litter. Waste Manag. 2017, 61, 138-149. [CrossRef]

12. Dias, B.O.; Silva, C.A.; Higashikawa, F.A.; Roig, A.; Sanchez-Monedero, M.A. Use of biochar as bulking agent for the composting of poultry manure: Effect on organic matter degradation and humification. Bioresour. Technol. 2010, 101, 1239-1246. [CrossRef] [PubMed]

13. Zimmerman, A.R. Abiotic and microbial oxidation of laboratory-produced black carbon (biochar). Environ. Sci. Technol. 2010, 44, 1295-1301. [CrossRef] [PubMed]

14. ASTM D1762-84. Standard Test Method for Chemical Analysis of Wood Charcoal; ASTM International: West Conshohocken, PA, USA, 2007.

15. Trautmann, N.M.; Kransy, M.E. Composting in the Classroom; Scientific Inquiry for High School Students; Cornell Waste Management Institute, Cornell University: Ithaca, NY, USA, 1997.

16. Zhang, L.; Sun, X. Changes in physical, chemical, and microbiological properties during the two-stage co-composting of green waste with spent mushroom compost and biochar. Bioresour. Technol. 2014, 171, 274-284. [CrossRef] [PubMed]

17. Rajkovich, S.; Enders, A.; Hanley, K.; Hyland, C.; Zimmerman, A.R.; Lehmann, J. Corn growth and nitrogen nutrition after additions of biochars with varying properties to a temperate soil. Biol. Fert. Soils 2012, 48, 271-284. [CrossRef]

18. Brewer, C.E.; Schmidt-Rohr, K.; Satrio, J.A.; Brown, R.C. Characterization of biochar from fast pyrolysis and gasification systems. Environ. Prog. Sustain. Energy 2009, 28, 386-396. [CrossRef]

19. Cao, X.; Harris, W. Properties of dairy-manure-derived biochar pertinent to its potential use in remediation. Bioresour. Technol. 2010, 101, 5222-5228. [CrossRef] [PubMed]

20. Leconte, M.C.; Mazzarino, M.J.; Satti, P.; Crego, M.P. Nitrogen and phosphorus release from poultry manure compost: The role of carbonaceous bulking agents and compost particle sizes. Biol. Fertil. Soils 2011, 47, 897-906. [CrossRef]

21. Hansen, V.; Müller-Stöver, D.; Ahrenfeldt, J.; Holm, J.K.; Henriksen, U.B.; Hauggaard-Nielsen, H. Gasification biochar as a valuable by-product for carbon sequestration and soil amendment. Biomass. Bioenergy 2015, 72, 300-308. [CrossRef] 
22. Pacioni, T.R.; Soares, D.; Di Domenico, M.; Rosa, M.F.; Moreira, R.F.P.M.; José, H.J. Bio-syngas production from agro-industrial biomass residues by steam gasification. Waste Manag. 2016, 58, 221-229. [CrossRef]

23. Yu, X.-Y.; Ying, G.-G.; Kookana, R.S. Reduced plant uptake of pesticides with biochar additions to soil. Chemosphere 2009, 76, 665-671. [CrossRef] [PubMed]

24. Brewer, C.; Unger, R.; Schmidt-Rohr, K.; Brown, R. Criteria to select biochars for field studies based on biochar chemical properties. Bioenergy Res. 2011, 4, 312-323. [CrossRef]

25. Sanchez-García, M.; Roig, A.; Sanchez-Monedero, M.A.; Cayuela, M.L. Biochar increases soil $\mathrm{N}_{2} \mathrm{O}$ emissions produced by nitrification-mediated pathways. Front. Environ. Sci. 2014, 2, 25.

26. Benitez, E.; Sainz, H.; Nogales, R. Hydrolytic enzyme activities of extracted humic substances during the vermicomposting of a lignocellulosic olive waste. Bioresour. Technol. 2005, 96, 785-790. [CrossRef] [PubMed]

27. Spokas, K.A. Review of the stability of biochar in soils: Predictability of O:C molar ratios. Carbon Manag. 2010, 1, 289-303. [CrossRef]

28. Abdulrazzaq, H.; Jol, H.; Husni, A.; Abu-Bakr, R. Characterization and stabilization of biochar obtained from empty fruit bunch, wood, and rice husk. Biol. Resour. 2016, 9, 2888-2898.

29. Wiedemeier, D.B.; Abiven, S.; Hockaday, W.C.; Keiluweit, M.; Kleber, M.; Masiello, C.A.; McBeath, A.V.; Nico, P.S.; Pyle, L.A.; Schneider, M.P. Aromaticity and degree of aromatic condensation of char. Org. Geochem. 2015, 78, 135-143. [CrossRef]

30. Yaman, S. Pyrolysis of biomass to produce fuels and chemical feedstocks. Energy Convers. Manag. 2004, 45, 651-671. [CrossRef]

31. Xue, Y.; Gao, B.; Yao, Y.; Inyang, M.; Zhang, M.; Zimmerman, A.R.; Ro, K.S. Hydrogen peroxide modification enhances the ability of biochar (hydrochar) produced from hydrothermal carbonization of peanut hull toremove aqueous heavy metals: Batch and column tests. Chem. Eng. J. 2012, 200, 673-680. [CrossRef]

32. Haberhauer, G.; Rafferty, B.; Strebl, F.; Gerzabek, M.H. Comparison of the composition of forest soil litter derived from three different sites at various decompositional stages using FTIR spectroscopy. Geoderma 1998, 83, 331-342. [CrossRef]

33. Thies, J.E.; Rilling, M.C. Characteristics of Biochar: Biological Properties; Lehmann, J., Joseph, S., Eds.; Biochar for Environmental Management, Science and Technology: London, UK, 2009; pp. 85-105.

34. Steiner, C.; Melear, N.; Harris, K.; Das, K.C. Biochar as a bulking agent for poultry litter composting. Carbon Manag. 2011, 2, 227-230. [CrossRef]

35. Schulz, H.; Dunst, G.; Glaser, B. Positive effects of composted biochar on plant growth and soil fertility. Agron. Sustain. Dev. 2013, 33, 817-827. [CrossRef]

36. Tejada, M.; Gonzalez, J.L. Crushed cotton gin compost on soil biological properties and rice yield. Eur. J. Agron. 2006, 25, 22-29. [CrossRef]

37. Kammann, C.I.; Schmidt, H.P.; Messerschmidt, N.; Linsel, S.; Steffens, D.; Müller, C.; Koyro, H.W.; Conte, P.; Joseph, S. Plant growth improvement mediated by nitrate capture in co-composted biochar. Sci. Rep. 2015, 5, 1-13.

38. Darby, I.; Xu, C.Y.; Wallace, H.M.; Joseph, S.; Pace, B.; Bai, S.H. Short-term dynamics of carbon and nitrogen using compost, compost-biochar mixture and organo-mineral biochar. Environ. Sci. Pollut. Res. 2016, 23, 11267-11278. [CrossRef]

39. Agegnehu, G.; Bass, A.M.; Nelson, P.N.; Bird, M.I. Benefits of biochar, compost and biochar-compost for soil quality, maize yield and greenhouse gas emissions in a tropical agricultural soil. Sci. Total Environ. 2016, 543, 295-306. [CrossRef]

40. Papafotiou, M.; Chronopoulos, J.; Kargas, G.; Voreakou, M.; Leodaritis, N.; Lagogiani, O.; Gazi, S. Cotton gin trash compost and rice hulls as growing medium components for ornamentals. J. Hort. Sci. Biotech. 2001, 76, 431-435. [CrossRef]

41. Zhang, Y.; Idowu, O.J.; Brewer, C.E. Using agricultural residue biochar to improve soil quality of desert soils. Agriculture 2016, 6, 10. [CrossRef]

42. Oldfield, T.L.; Sikirica, N.; Mondini, C.; López, G.; Kuikman, P.J.; Holden, N.M. Biochar, compost and biochar-compost blend as options to recover nutrients and sequester carbon. J. Environ. Manag. 2018, 218, 465-476. [CrossRef] [PubMed]

43. Yuan, Y.; Chen, H.; Yuan, W.; Williams, D.; Walker, J.T.; Shi, W. Is biochar-manure co-compost a better solution for soil health improvement and $\mathrm{N}_{2} \mathrm{O}$ emissions mitigation? Soil Biol. Biochem. 2017, 113, 14-25. [CrossRef]

44. Díaz, M.J.; Madejón, E.; López, F.; López, R.; Cabrera, F. Composting of vinasse and cotton gin waste by using two different systems. Resour. Conserv. Recycl. 2002, 34, 235-248. [CrossRef] 